\title{
АНАЛІЗ ФУНКЦІОНУВАННЯ СИСТЕМ УПРАВЛІННЯ БЕЗПЕКОЮ РУХУ ПОӤЗДІВ НА ЗАЛІЗНИЦЯХ КРАЇН ЄВРОСОЮЗУ
}

\author{
К-т техн. наук О.В. Розсоха, здобувач Ю.В.Смачило
}

\section{АНАЛИЗ ФУНКЦИОНИРОВАНИЯ СИСТЕМЫ УПРАВЛЕНИЯ БЕЗОПАСНОСТЬЮ ДВИЖЕНИЯ НА ЖЕЛЕЗНЫХ ДОРОГАХ СТРАН ЕВРОСОЮЗА}

\author{
К-т техн. наук А.В. Розсоха, соискатель Ю.В.Смачило
}

\section{ANALYSIS OF THE FUNCTIONING OF THE SAFETY MANAGEMENT OF THE RAILWAYS OF THE EUROPEAN UNION COUNTRIES}

\section{Candidate of techn. scienes O.V. Rozsoha, applicant Y.V.Smachilo}

Проведено аналіз функиіонування систем управління безпекою руху поїдів на залізнииях країн Євросоюзу після проведення реформи європейського залізничного простору. Управління безпекою руху вимагає нових підходів, реалізація яких повинна внести суттєві корективи в нині чинну систему управління безпекою перевезень. У висновку наведений досвід краӥн Європейського Союзу, який є актуальним і для Украӥни.

Ключові слова: безпека руху поӥздів, системи управління безпекою руху, ефективність роботи залізниць, досвід країн $Є C$.

Проведен анализ функционирования систем управления безопасностью движения поездов на железных дорогах стран Евросоюза. После проведения реформы европейского железнодорожного пространства. Управление безопасностью движения требует новых подходов, реализащия которых должна внести существенные коррективы в ныне действуюшую систему управления безопасностью перевозок. В заключении приведен опыт стран Европейского Союза, который является актуальным и для Украиньл.

Ключевые слова: безопасность движения поездов, системы управления безопасностью движения, эффективность работы железных дорог, опыт стран ЕС.

The analysis ofthe functioning ofthe safety management systemof trains onthe railways of the European Union countriesafter the reform of the European railway area. The article discusses the four railway package directives and their results for example, such as the establishment of The European Railway Agency and new safety authorities. The European Railway Agency was set up to help create this integrated railway area by reinforcing safety and interoperability. The governments of European countries have different attitudes toward the European Union directives, there is no single right approach. And now it is clear that safety management requires new approaches, the implementation of which should make significant adjustments to the current system of safety management services.The conclusion shows the experience of the European Union countries (positive experience of Germany, challenging experience of United Kingdom and aresponsible approach of Poland) which is useful for Ukraine.

Keywords: traffic safety, traffic safety management system, the efficiency of the railways, the experience of the EU countries. 
Вступ. Відповідно до Транспортної стратегії України на період до 2020 року (розпорядження Кабінету Міністрів України від 20 жовтня 2010p. № 2174-p) одним із i очікуваних результатів $\epsilon$ прискорення темпів інтеграції вітчизняної транспортної системи до європейської та світової транспортних систем 3 максимальним використанням транзитного потенціалу держави.

Інтеграція, в свою чергу, $є$ неможливою без підвищення рівня безпеки руху на залізничному транспорті України.

Безпека руху на залізничному транспорті залишається однією 3 самих важливих проблем, оскільки без належного рівня безпеки руху функціонування всього залізничного сегменту неможливе.

Постановка проблеми. Приймаючи до уваги вище зазначене, актуальними $\epsilon$ дослідження, які спрямовані на підвищення рівня безпеки у системі управління рухом поїздів на залізницях України. Один із напрямків, який допоможе у вирішенні цього питання, є аналіз досвіду країн Євросоюзу.

Аналіз досліджень і публікацій. Вагомий внесок у побудову принципів створення i розвитку теорії розрахунку показників надійності роботи та безпеки руху залізничного транспорту зробили такі вчені, як: Т.В. Бутько, В.Я. Болотний, Б. Грау, П.С. Грунтов, І.В. Жуковицький, Г.І. Загарій, О.М.Замишляєв, В.А. Кобзєв, Ф.П. Кочнєв, В.М. Лисенков, М.К. Модін, В.Я. Негрей, В.М. Образцов, Ю.О. Пазойський, М.В. Правдін, В.В. Сапожников, І.Б. Сотніков, М.Я. Стефанов, I.I. Страковський, М.Г. Шабалін та ін. [1].

Підходи щодо визначення рівня безпеки руху на залізничному транспорті були в основному спрямовані на отримання результату за окремою групою показників. Комплексній оцінці системи управління безпекою руху поїздів уваги значно не приділялось.

Формулювання мети (постановка завдання). Метою даного дослідження $\epsilon$ вивчення та аналіз досвіду реформування структури системи безпеки руху поїздів у країнах Свросоюзу, визначення умов необхідності зміни моделі управління та розробка в подальшому науково обгрунтованої методології перспективного реформування організаційної структури управління безпекою руху на залізничному транспорті України.

Аналіз досвіду країн Європейського союзу у період реформування. Останнє десятиліття охарактеризувалося значними структурними змінами у сфері залізничного транспорту країн Свросоюзу.

3 другої половини XIX ст. i до початку $\mathrm{XX}$ ст. частка залізничного транспорту на ринку транспортних послуг Європи значно знизилась. Задля усунення негативної тенденції та збільшення частки залізничного транспорту Європейська комісія організувала реформу європейського залізничного простору, яка була розділена на три етапи, які також відомі, як «залізничні пакети»[2]. Етапи реформи європейського залізничного простору наведено на рис. 1.

Перший «залізничний пакет» включає Директиви 2001/12/СC，2001/13/СC та 2001/14 /СС, які були прийняті в 2001 році. Директива 2001/12/ ЄС змінюе та оновлює директиву 91/440/ЄC, яка пропонує розділення операторської діяльності та управління інфраструктурою. Директива 2001/13/СС в свою чергу змінює Директиву 95/18/СС («ліцензування залізничних підприємств»). Остання Директива пакету 2001/14/ЄС стосується розподілу пропускної здатності залізничної інфраструктури, стягнення зборів за користування залізничною інфраструктурою та сертифікації безпеки.

Законодавчий пакет, прийнятий в 2001 році, являє собою перший крок на шляху відродження залізниць за допомогою поступового створення інтегрованого на європейському рівні "залізничного простору", зокрема в результаті відкриття ринків залізничних вантажних перевезень i визначення умов доступу залізничних підприємств до залізничної інфраструктури.

Слідом за «першим пакетом» Європейською комісією було розроблені та затверджені ще другий пакет та третій пакет (2007 року 3 Директивами 2007/58/ EC, 2007/59/ СC, 2007/57/ СС та регламентом 1371/2007/ СС в якому йдеться про права пасажирів). 

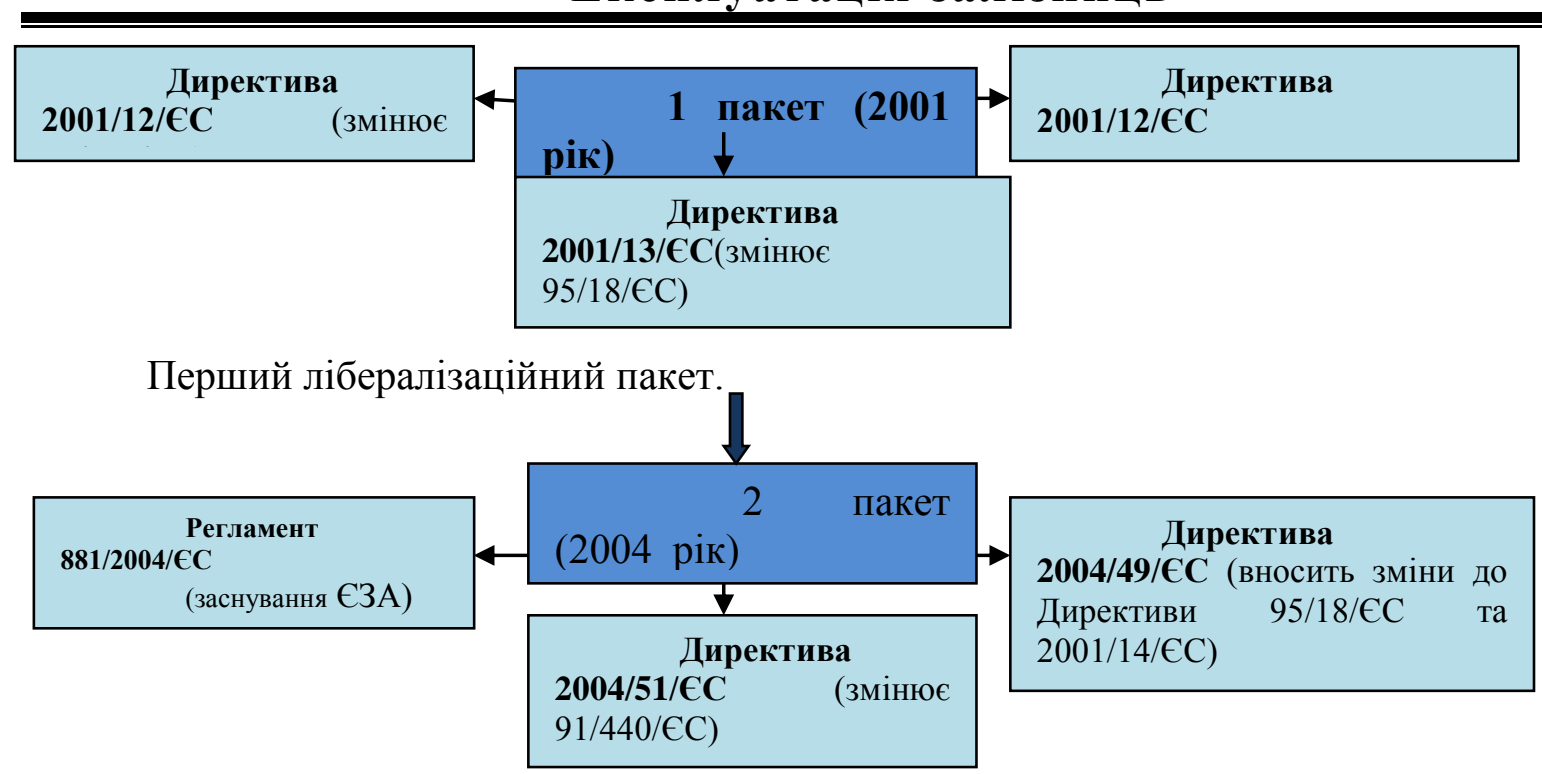

Заснування Свропейського залізничного агентства(ЄЗА).

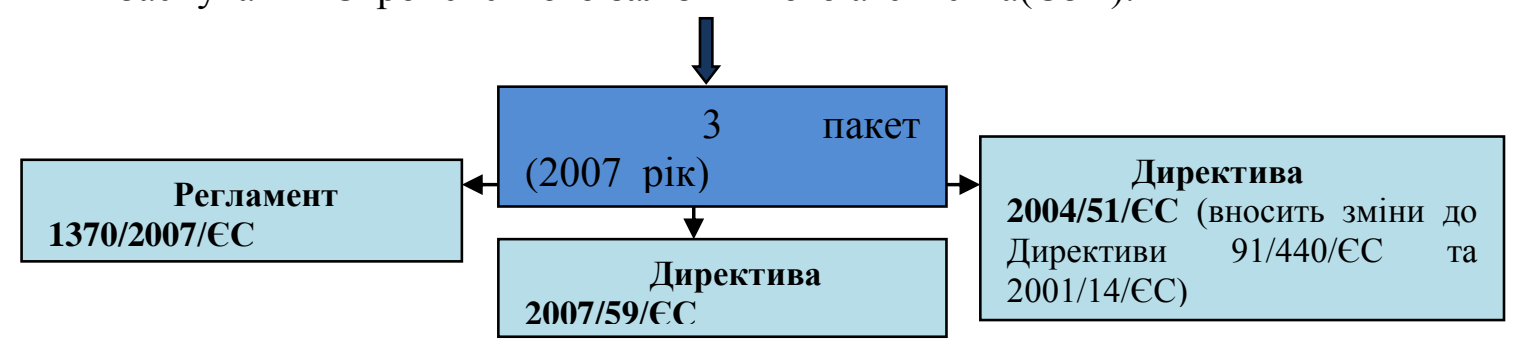

Створення конкурентного ринку пасажирських послуг.

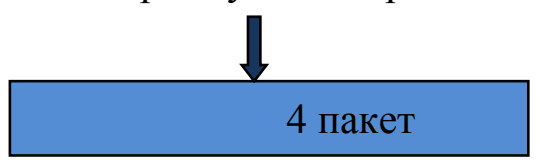

Станом на жовтень 2014 року 4 пакет залізничних реформ був прийнятий Європейською комісією, але ще не був схвалений в Європейському парламенті.

Рис. 1. Етапи реформи європейського залізничного простору.

Другий пакет директив був прийнятий у 2004 році. Він включає в себе регламент $881 / 2004 / € C$, за допомогою якого було офіційно створене Європейське залізничне агентство, діяльність якого в повному обсязі почалася в 2006 році. Головною метою Європейського залізничного агентства $\epsilon$ створення i розвиток загальних технічних стандартів (включаючи TSI), працюючи при цьому разом 3 державними і європейськими установами, а також здійснення контролю над країнами-учасниками у питання виконання директив. Кожного року Європейське залізничне агентство розробляє річний звіт з яким можна ознайомитися на офіційному сайті агентства.

Також другим пакетом затверджена директива 2004/51/ СС «розвиток залізниць
Співтовариства», яка замінює директиву 91/440/CC.

Директива 2004/49/СС Європейського Парламенту та Ради «Про безпеку залізниць у Співтоваристві», яка вносить зміни до Директиви Ради 95/18/СС «Про ліцензування підприємств залізничного транспорту» та до Директиви 2001/14/СС «Про розподіл потужностей залізничних інфраструктур та стягнення платежів за використання залізничної інфраструктури та про сертифікацію безпеки» також була затверджена у 2004 році.

Можна виділити основні підходи даної Директиви 2004/49/СС:

1) оскільки до сьогоднішнього часу існують певні відмінності у підходах виконання завдань, пов'язаних 3 управлінням безпекою руху, то завданням 
Єврокомісії $\epsilon$ визначення єдиних рамок, які повинні застосовуватися в усіх країнах. Кожна держава самостійно визначає цілі, стежить за їх досягненням, встановленими законодавчими рамками, i аналізує дані. Вони передаються до Єврокомісії у вигляді щорічного звіту.

«Кожен рік усі менеджери інфраструктур та залізничних підприємств подають до органу з безпеки до 30 червня річні звіти за попередній календарний рік. Звіт про безпеку вміщує:

- інформацію про рівень досягнення організацією корпоративних цілей в галузі безпеки та результати виконання планів 3 безпеки;

- розвиток національних показників безпеки, a також загальних показників безпеки;

- результати внутрішнього аудиту стану безпеки;

- спостереження за нестачами та невірне функціонування залізничної діяльності та управління інфраструктурою, які можуть бути відповідними компетенції органу з безпеки» [3];

2) кожна держава-член повинна створити незалежний орган 3 питань безпеки.

«Цим органом може бути міністерство, відповідальне за питання транспорту. Цей орган $\epsilon$ незалежним від залізничних підприємств, менеджерів інфраструктури, заявників та підприємств матеріально-технічного забезпечення із організаційно-правовою структурою та певним порядком прийняття рішень» [3];

3) створення незалежного органу розслідування.

«Цей орган $є$ незалежним по своїй організаційно-правовій структурі та порядку прийняття рішень від будь-яких менеджерів інфраструктури, залізничних підприємств, органу, що стягує плату, розподільного органу та уповноваженого органу, а також від будь-якої сторони, чиї інтереси можуть суперечити завданням, покладеним на орган 3 розслідувань. Більш того, він $\epsilon$ функціонально незалежним від органу 3 безпеки та від будь-кого, хто регулює діяльність залізниць» [3];
4) всі залізничні підприємства, які хочуть отримати доступ до інфраструктури залізниць повинні отримати сертифікат безпеки, який в свою чергу засвідчує, що підприємство створило свою систему управління безпекою та може виконувати всі встановлені вимоги у сфері управління безпекою. Сертифікат видається органом 3 питань безпеки.

Також існує четвертий пакет залізничних реформ, в якому комісія пропонує далекосяжні заходи зі стимулювання більшої кількості інновацій на залізничному транспорті $\mathrm{CC}$, відкривши внутрішні пасажирські ринки $Є С$ для конкуренції, а також суттєві супутні технічні та структурні реформи.

Станом на жовтень 2014 року четвертий пакет залізничних реформ був прийнятий Свропейською комісією, але ще не був схвалений в Свропейському парламенті.

В даний час управління безпекою руху у зв'язку з появою нових організацій та власників у різних країнах Європейського Союзу здійснюється по-різному. Нижче наведено приклади таких країн, як Німеччина, Великобританія та Польща.

1 січня 1994 було покладено початок фундаментальної реструктуризації залізниць Німеччини. Федеральні і Державні залізниці, що існували у вигляді державної власності, були перетворені в акціонерне товариство, орієнтоване на отримання прибутку i 3 можливістю здійснювати підприємницьку діяльність - "Залізниці Німеччини" (Deutsche Bahn AG - DBAG). Сдиним акціонером стала держава.

Для досягнення цього, крім зміни Конституції, потрібно було внести поправки в цілому в 136 федеральних державних законів, але залізниці Німеччини змогли створити ефективні методи забезпечення безпеки руху та експлуатації залізничного транспорту.

3 відкриттям ринку в загальну систему управління безпекою вступали нові компанії-оператори перевезень. Значна кількість таких компаній-операторів, які в свою чергу мають різний досвід і культуру виробництва, створювали складнощі для існуючої системи забезпечення безпеки. 
Оскільки існують певні відносини між підприємствами 3 управління інфраструктурою і компаніями-операторами стало зрозуміло, що потрібні в застосуванні особливі заходи контролю між ними.

Організаційна структура залізниць Німеччини наведена на рис.2 [4].

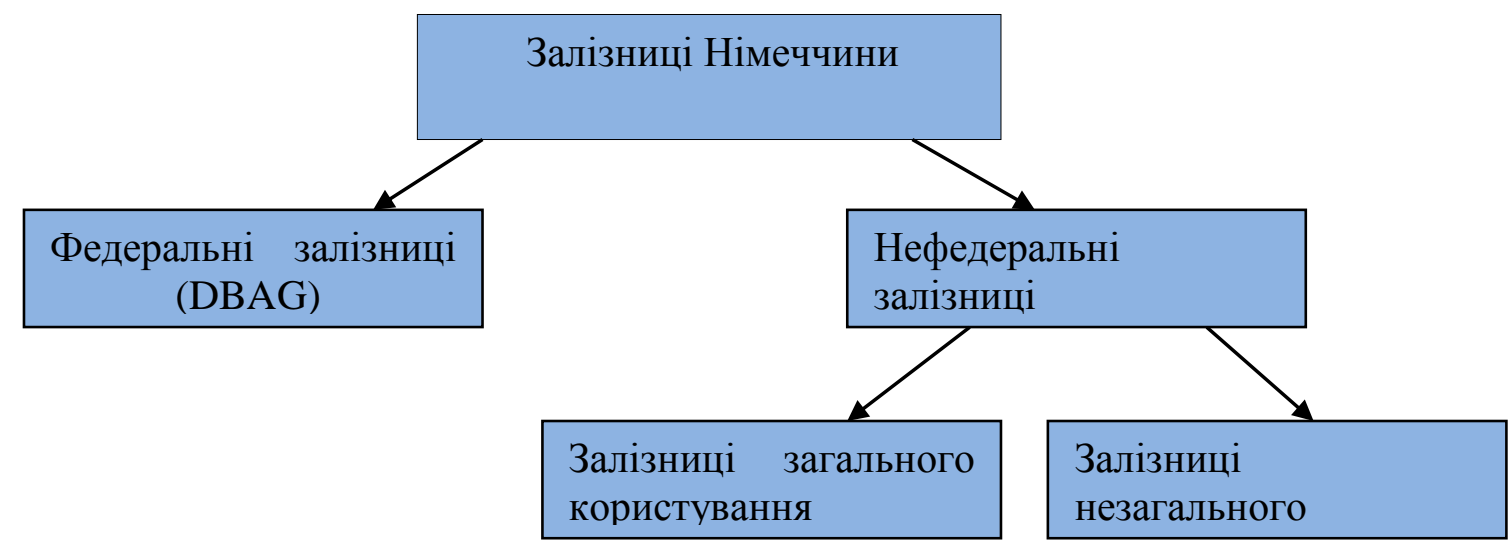

Рис. 2. Організаційна структура залізниць Німеччини

Після ряду правових змін у Німеччині «Загальний закон про залізниці» зобов'язує залізничні підприємства будувати рухомий склад, споруди та допоміжні засоби 3 великим ступенем надійності, утримувати їх у безпечному стані, а також забезпечувати безпеку експлуатації залізничного транспорту.

Для ліцензованих перевезень, кожна компанія-оператор має отримати сертифікат безпеки, який засвідчує, що компаніяоператор спроможна здійснювати перевезення у встановлених вимогах, відповідає дійсним стандартам. Сертифікат безпеки видається на підставі заяви компанії спеціалізованим уповноваженим органомФедеральним залізничним агентством Федеративної Республіки Німеччини.

Розслідування нещасних випадків проводиться незалежним органом - Слідчим комітетом з розслідувань залізничних аварій, який почав свою роботу в 2007 році.

На даний час на залізницях Німеччини нараховується більше двохсот компаній-операторів, але рівень безпеки залишається досить високим. В порівнянні із початком дореформеного періоду, рівень транспортних подій зменшився втричі, із чого можна зробити висновок про спостереження позитивної тенденції змін [5]. Досвід Німеччини значно відрізняється від досвіду Великобританії, яка була першопрохідцем у питанні приватизації залізниць після прийняття Директиви 91/440/CC.

Після продажу, основна відповідальність за забезпечення безпеки експлуатаційного процесу залізниць була покладена на одну 3 новоутворених приватних компаній, власника-розпорядника залізничної інфраструктури «Rail track».

За два роки вартість акцій зросла на $70 \%$, запізнення поїздів скоротилися на 30 \%. 3'явилися додаткові послуги у поїздах та вокзалах, які також належали компанії «Rail Track». Уряд був задоволений, було скорочено субсидії у залізничний транспорт, а пасажири одержали право вибору найбільш зручного виду транспорту [6].

Після позитивних змін компанію «Rail Track» спіткала невдача через кількох помітних аварій, включаючи катастрофу в Хетфілді (причиною стало руйнування рейок через мікроскопічні тріщини). Після цієї аварії інфраструктурна компанія «Railtrack» ввела більш 1200 обмежень швидкості по всій мережі і почала надзвичайно дорогу строкову програму заміни рейок по всій країні. Тривалі затримки поїздів і колосальні витрати компанії призвели до банкрутства компанії i заміни іiі державною некомерційною організацією.

$$
\text { В даний час проводиться }
$$
удосконалення законодавства, стандартизації, перерозподілу функцій між державними i приватними секторами 
економіки. Також проходить робота 3 більш ніж сотнею приватних компаній-операторів у питаннях безпеки руху.

Було створено незалежний орган 3 безпеки - Офіс залізничного регулювання (OfficeoRailRegulation), який діє в рамках встановленого Великобританією i Євросоюзом законодавства і фінансується за рахунок залізничної галузі.

Органом 3 розслідування нещасних випадків та інцидентів, які відбуваються за залізницях Великобританії $є$ Філія 3 розслідувань залізничних подій (Rail Accident Investigation Branch's), яка почала працювати 3 жовтня 2005 року. Філія є частиною Департаменту транспорту, але функціонально незалежною.

Європейською залізничною агенцією Залізниці Великобританії були визнані найбезпечнішими у 2013 році.

Досвід Польщі буде наступним. Власником залізниць Польщі є держава в особі акціонерного товариства «Польські державні залізниці». 31 січня 2001 року після приватизації підприємства «Польські державні залізниці» єдиним власником акцій стало Міністерство Інфраструктури.

Одне 3 основних правил, що стосується залізничного сектора Польщі, відноситься до відповідальності. У відповідності 3 підходом, прийнятим як в національному, так i європейського законодавстві, всі суб'єкти, що діють в системі залізниць несуть відповідальність за iii безпечну експлуатацію. Менеджери залізничної інфраструктури, та залізничні перевізники відіграють особливу роль у цій галузі, оскільки їх діяльність впливає на безпеку у всьому секторі. Тим не менш, цей факт не звільняє інших суб'єктів, що діють в рамках залізничної системи, від забезпечення безпеки, і кожен 3 них несе також відповідальність. Отже відповідальність за безпеку всіє залізничної системи забезпечується колективними зусиллями.

Для забезпечення безпеки перевезень, менеджери залізничної інфраструктури, які надають залізничні перевезення, і будь які залізничні оператори, що надають послуги, використовуючи цю інфраструктуру, зобов'язані підготувати, сертифікувати і здійснювати на практиці так звану Систему управління безпекою (SMS). Ця системи являє собою набір процедур, які регулюють основні напрямки діяльності компанії 3 точки зору безпеки.

У 2012 році відповідно до інформації, представленої в першій частині доповіді Польської Республіки, більше ніж 60 залізничних перевізників працювали на території Польщі, надаючи послуги в пасажирському та вантажному сегменті. 10 перевізників діяли в якості менеджерів інфраструктури, більшість із яких (вісім організацій) працювали на основі ліцензії (системному підході), в той час, як два - на основі сертифікату безпеки.

Перед початком експлуатації будьякий транспортний засіб закріпляється за Підрозділом який відповідає за технічне обслуговування. Організація, яка відповідає за вантажні вагони, обов'язково повинна мати сертифікат, який можна отримати після розробки і отримання сертифікату Системи управління і технічного обслуговування, в рамках якого вся відповідальність за процеси, які виконуються 3 даним транспортним засобом (процес планування, управління, здійснення операцій по технічному обслуговуванню) несеться спеціалізованим підрозділом.

Окрім організацій в залізничному секторі слід відмітити і певні умови, які складали основу для створення загальних понять безпеки залізничної системи на рівні державного управління.

Через лібералізацію залізничного сектора 3 постійно зростаючою кількістю організацій, органи державної влади не могли і не повинні були прийняти на себе відповідальність за безпеку руху. Роль держави зводилася до вирішення трьох основних проблем:

- забезпечення належної правової бази, яка дозволить працювати у сфері залізничних перевезень;

- перевірка спроможності виконувати юридичні вимоги і працювати в безпечній манері в залізничному секторі перед виходом новоствореної організації на ринок;

- контроль за постійним дотриманням вимог, які є основою для виходу на ринок залізничних перевезень. 
Функції Національного органу Ця схема включає в себе шість основних безпеки виконує Президент Служби етапів, в рамках яких органи державного Залізничного Транспорту. Цикл впливу управління можуть позитивно вплинути на органу безпеки на залізничну систему рівень безпеки підприємств залізниць і всієї Польщі наведено у вигляді схеми на рис. 3. системи залізниць.

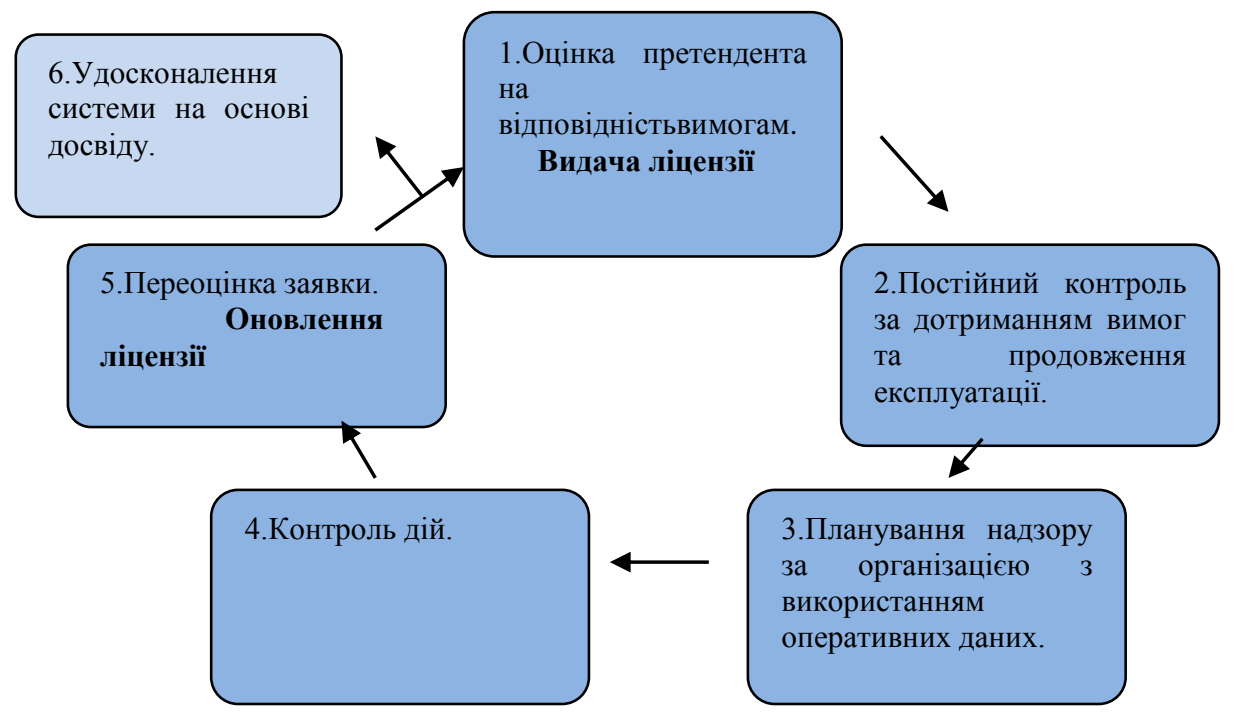

Рис. 3. Цикл впливу органу безпеки на залізничну систему Польщі

Функції Національного органу 3 розслідувань транспортних подій виконує Державна комісія 3 розслідування залізничних аварій [7].

Укрзалізниця - одна із останніх серед європейських залізничних адміністрацій розпочала процес реформування, обравши за приклад модель Німеччини, Польщі, Франції, Росії, в яких $\epsilon$ інтегрована інфраструктурна компанія, тобто перевізник, який володіє інфраструктурою.

Як і в країнах Свропейського Союзу реформування структури управління залізничним транспортом України треба виконувати поступово.

Процес реформування в залізничній галузі України буде здійснюватися трьома етапами.

Метою першого етапу реформування є створення акціонерного товариства загального користування у вигляді ПАТ «Укрзалізниця», $100 \%$ акцій якого буде закріплено в державній власності. Зараз проходить оцінка активів, яким займається компанія Deloitte. Після завершення оцінки відбудеться процедура реєстрації акціонерного товариства, яка очікується восени 2015 року. Реєстрація акціонерного товариства дозволить розділити державні і господарські функції управління, поклавши їx на державні органи i акціонерне товариство відповідно.

На другому етапі відбудеться формування вертикально інтегрованої виробничо-технологічної системи залізничного транспорту, структурованої за видами діяльності, 3 упровадженням автоматизованої системи обліку та управління, а також утворення головного та регіональних центрів управління перевезеннями.

До 2019 року планується ліквідація перехресного субсидування пасажирських перевезень за рахунок вантажних шляхом впровадження механізму фінансової підтримки пасажирських перевезень. Третій етап передбачає збільшення кількості приватних компаній, що володіють парком пасажирських вагонів.

Одним із головних очікуваних результатів програми стане підвищення рівня безпеки руху.

\section{Висновки.}

3 досвіду реформування країн Європейського Союзу можна зробити такі висновки:

1) реформа у сфері залізничного транспорту України можлива лише у тандемі 
3 розробкою і удосконаленням законів, низки нормативних актів, які допоможуть працювати реформам, тобто створення відповідного нормативного поля;

2) після проведення третього етапу реформ через збільшення кількості приватних перевізників виникне необхідність в розробці системи ліцензування, отримання сертифікатів безпеки, без яких перевізники не зможуть розпочати роботу в галузі;

3) як показав досвід Великобританії, держава не повинна нести всю відповідальність за безпеку руху одноосібно. За державою повинна залишитись функція контролю над цими суб'єктами;

4) отриманий дорогою ціною досвід Великобританії є актуальним і для України, даючи можливість заощадити час і кошти в складний перехідний період;

5) проведення реформ потягне за собою створення додаткових структур: залізничних агентств, незалежних органів безпеки з розслідувань транспортних подій.

\section{Список використаних джерел}

1. Розсоха, О.В. Аналіз функціонування системи управління безпекою руху поїздів на залізницях України [Текст] / О.В. Розсоха, М.В. Люлін, О.В. Щербина // Залізничний транспорт України. - 2013. - № 5/6. - С. 21-25.

2. Европейская реформа железных дорог. Три ж/д пакета [Електронний ресурс] // Железные дороги Мира - Режим доступу до ресурсу : http://1430mm.ru/node/216.

3.Директива 2004/49/СС Європейського Парламенту та Ради "Про безпеку залізниць у Співтоваристві, яка вносить зміни до Директиви Ради 95/18/ЄС про ліцензування підприємств залізничного транспорту [Електронний ресурс] // Офіційний веб-портал Верховної Ради України. - 29.04.2004. - Режим доступу до ресурсу : http://zakon4.rada.gov.ua/laws/show/994_953.

4.Берндт Т. Структура и особенности железных дорог в Германии / Т. Берндт, С. В. Власенко. // Железные дороги мира. - 2007. - №2. - С. 17-20.

5.Обеспечение безопасности движения: европейский опыт [Електронний ресурс] / Л. Н.Павлов, Т. Н. Зайцева, О. Л. Целищева, В. Г. Майоров // Железнодорожный транспорт. 07.05.2007. - Режим доступу до pecypcy : $\underline{\text { http://www.zdt- }}$ magazine.ru/publik/zarubeg/2007/may07.htm.

6. Бараш Ю. С.Аналіз реформування структур управління залізничним транспортом у розвинених країнах Свропи [Електронний ресурс] / Ю. С. Бараш // Вісник Дніпропетровського національного університету залізничного транспорту імені академіка В. Лазаряна . - 2003. - Вип. 1. - С. 158-162. - Режим доступу : http://nbuv.gov.ua/jpdf/vdnuzt_2003_1_33.pdf

7.Polish Railways in 2012 - market operation and traffic safety [Електронний ресурс] // Urząd Transportu Kolejowego. - 25.04.2014. - Режим доступу до ресурсу : http://utk.gov.pl/download/3/7380/raportv2ENfullres.pdf.

$$
\text { Рецензент д-р техн. наук. професор О.М.Огар }
$$

Розсоха Олександр Володимирович, кандидат технічних наук, доцент кафедри залізничних станцій та вузлів, Українська державна академія залізничного транспорту. Тел.: (057) 730-10-42.

Смачило Юлія Володимирівна, здобувач наукового ступеню кафедри залізничних станцій та вузлів, Українська державна академія залізничного транспорту. Тел.: (057) 730-10-42.

O.V. Rozsoha, candidate of techn. scienes,assistant professor at the department of railway stations and junctions,Ukrainian state Academy of Railway Transport. Tel.: (057) 730-10-42.

Y.V. Smachilo, applicant at the department of railway stations and junctions,Ukrainian state Academy of Railway Transport. Tel.: (057) 730-10-42. 